\title{
A Memorandum on the Photograph: Movement and Time in Blurs and Stills
}

Prints taken and developed by a photographer used to be called "pictures," and films taken by a cinematographer used to be called "photographs," nowadays, however, we never see or hear these words being used in this way; except by those who delight in bucking the current trend (or, at least, appearing to), with the pride of a computer geek. ${ }^{1}$

Of course, this kind of inverted snobbery may well have been shared by the avantgarde who set themselves against bourgeois perspectives on Art, as defined by Gustave Flaubert's Dictionary of Received Ideas: "What is its point now that its place has been taken by mechanical processes that are 'faster and superior'?" And it is precisely from such bourgeois conceptions of Art that "paintings," "photographs," and "films" might in turn be seen as graduated technological advancements with each development superseding the last, so that whereas daguerreotypes simply "take the shine off painting," photographs "consign painting to the dustbin."2

Having said that, there are a few instances where various terms used to describe projected images were initially formed in relation to their specific technological innovations

Translated by Hannah Osborne. Originally published as Kanai, Mieko, "Fotogurafu oboegaki - ugokumono to ugokanai mono no kyori" (A Memorandum on the Photograph: Movement and Time in Blurs and Stills) in "Kyōsō aite wa baka bakari" no sekai e yōkoso (Welcome to the World where 'All Rivals are Idiots') Tokyo: Kodansha, 2003; republished in Kanai, Mieko, Kanai Mieko Essei korekushon (1964-2013) 4: Eiga, yawarakai hada. Eiga ni sawaru (Kanai Mieko's Essay Collection (1964-2013) Vol 4: Films and Soft Skins. Being Touched by Film) Tokyo: Heibonsha, 2014.

${ }^{1}$ The beginning of this essay may be a little disorientating for English readers as Kanai writes that what we now term as "photographs" (shashin) used to be called "pictures" (e), and "films" (eiga) used to be called "photographs" (shashin); whereas in English it was common to refer to photographs as "pictures" and films as "the pictures."

Kanai repeatedly uses and italicizes the term bure (literally, "a blur") throughout the essay, not only to emphasize where shifts in terminology and movement in images occur, but also to replicate textually that very sense of blurring, change, or movement. The idiomatic and grammatical ways in which bure is used in Japanese cannot be represented in English by a single translation; therefore, I have chosen not to replace it with a single term, but have used "trend" and "shift," as well as "blur"; in each case, however, I have retained the italics. ${ }^{2}$ In translating Kanai's passage here, I have attempted to maintain an essence of the Japanese translation of Flaubert's Le Dictionnaire des idées reçues (1911) to which Kanai refers. Flaubert's satirical dictionary, of course, replaces definitions with bourgeois attitudes toward the thing satirically being defined. Thus, "Art" is glossed "A quoi ça sert? Puisqu'on le remplacer par des mécaniques qui font "mieux et plus vite"”; "daguerréotype" as "remplacera la peinture" (will take the place of painting); and "photographie" as "détrônera la peinture" (will supplant painting). 
- "plate" for the icon that the pinhole camera obscura copied onto a silver coated plate; "paper prints" for the printed image of the photograph upon paper; and finally "film" for the material on to which photographs are strung together to make moving images - but have now shifted in the application of their meaning. At first, then, naming these parts was simply a matter of technical accuracy; calling "videotapes" that we watch on our television screens "films" as we do now, however, seems like a completely different exercise.

When I started this essay, I intended to write about how photographs appear in films; but before I do so, I wish to write about how, within the moment of the unmoving fixed image of a photograph (or drawing of light) - a moment measured by the speed of the camera's shutter - there lives a subtle cinematograph (or drawing of movement):

In summer, canna lilies of all colors bloomed. In our garden they grew taller than the adults, and to me they seemed like a grove of trees. One day, our whole family formed two lines in front of those lilies. I can picture it now; a box-shaped camera pointing toward us, next to which stood a man I didn't know. I was being held by my mother at the end of one line. We faced the main road, so our main residence was off to the left; and I could see my grandmother perched on its veranda. My elder sister and brother took turns to go and speak to her about something, but she didn't get up. So then, having decided to leave my grandmother out, we must have all turned toward the box-shaped thing; but, this time, the strange man started talking very earnestly to me. Saying things like, "Hey, wait for the lil birdie to pop up!" he tried very hard to catch me smiling, as he pointed to the box covered with a black cloth. In our house we never once used baby words like lil birdie, so I remember that phrase extremely well; and I of course realized that the man was doing his best to divert me. Well, that lil birdie never did show its face. And it wasn't until many years later, when looking at the photograph, that I realized what had been going on at that moment. While everyone else had appropriate smiles fixed upon their faces, only I, being held by mother, have this smudgy blur. Although I remember the scene well, I was surprised to see that I'd been so young that I'd not been able to stay still even for the duration of a photograph being 
snapped; and I finally understood why the photographer had been speaking so earnestly to me and me alone. ${ }^{3}$

(Ishii Momoko, A Story of Youth)

With the invention of the shutter, the camera lens, and photosensitive film, the camera made it possible to fix any rapidly moving physical subject to a single point in time within a single frame; and perhaps this is the divine purpose for which the photograph was meant to exist: so that Edgar Degas could draw movement as blurs of light in his ballerina photographs; so that Robert Capa could work around the problem of ethics implicit in photo journalism by blurring the photos' focus; so that, in an act, not of ethics, but rather of adventurousness, curiosity, and ambition, James Stewart in Rear Window would break his leg in order to capture the decisive moment in a racing accident; and, finally, so that David Hemmings in Blow-Up who, in attempting to snap a photo of a couple fooling around together, would later discover images in his camera's film that he'd had no intention of taking, of both a dead body and the murderer. But of course, even if you have never seen Ishii Momoko's family photo, clearly a child's memory of being taken as a blur speaks about more things than can be captured in one photo, as there are many motivations behind any desire to brand onto paper (print) and stretch out (enlarge) an image into a photograph so that everyone can view it. As I was writing this, I stopped, or rather, had a sudden start, remembering that many years ago I had bought a photo collection by Claude Simon; ${ }^{4}$ however, after searching every last book case in my house I still cannot find it, and am wondering whether I ever had such a thing: was it an acacia outside that window, or was it a sycamore, on whose leaves and branches the sun shines, and are they trembling because the wind is blowing, or do they just seem to be doing so because the camera's focus is

\footnotetext{
${ }^{3}$ An excerpt from Ishii Momoko's autobiography, Osana monogatari (A Story of Youth), 1981. Ishii (1907-2008) is a well-known translator of children's literature and children's writer in Japan. She translated A. A. Milne's Winnie-the-Pooh in 1940 and made her debut as an author with Non-chan kumo ni noru (Non-chan rides on a cloud) in 1947.

${ }^{4}$ Claude Simon (1913-2005) the French novelist often associated with the nouveau roman movement, won the Nobel Laureate for Literature in 1985. His novel La Route de Flandres (The Route to Flanders) was published in 1960 and earned him the literary prize, L'Express and international recognition; he later produced the novels Histoire (History) in 1967, Les Géorgiques (The Géorgiques) in 1981 and L'Acacia (The Acacia) in 1989 all center on the theme of family history. In this essay Kanai refers to and quotes from his novel Le Vent (The Wind, 1957).
} 
completely out?; had I really seen those photos of children's doodles of simple circles and doll shapes chalked on stone paving, and a bunch of down-and-outs leaning and sitting on street walls, their once neatly shorn hair now scruffily grown - photos that seemed extremely unclear and that made me pause in deciding whether or not this was because they were the result of images' having been enlarged in order to be printed?; had I really seen those photos in which the subjects snapped could be thought of, not as just ordinary, but moreover, as refusing all empathy with their onlookers? I even became a little bit nervous contemplating whether Simon's photographs, which create shapes by shading irrefutably distinctive black and white outlines that insist upon their being, were rejecting, for instance, the violent wind, light and matter of Straub and Huillet's Cézanne. ${ }^{5}$ Aren't those incarcerated in the art gallery / psychiatric ward / prison drawn from the same light as Cézanne's photographs?

And although I cannot find Simon's photo collection, his words still linger: "wasn't there something like this just there?"; "wasn't that just like this?" For instance, I remember lines such as: "The sycamore branch almost reaches the small window, and at night time the street light projects the ceaselessly moving shadow of the branch and its shimmering collection of sword-like leaves onto the ceiling; their patterns forever disentangling, parting slightly, then falling back into themselves." And, "all day long the village green rather resembled what we might call a meadow, and his daily life was free from cares," "and then, from his window every day, Montès was able to watch the calm, irresistible rebirth of life or rather, the unchanging succession of unchanging stages in which seedlings appear, then sprout as a glorious, mystical, and dreamlike pulsation, their delicate buds swaying in the ceaseless wind, swelling, silently bursting and plastering the entire scene, that reminded him of something. [...] At other times he would go and sit on one of the benches up on the mound in the village green wearing rags with his hair like a bird's nest and watch the

\footnotetext{
5 Jean-Marie Straub (1933-) and Danièle Huillet (1936-2006), French filmmakers who worked together to make over twenty films that drew upon literature, plays, political writings and opera to deliver radical communist critiques of culture and society. The film that Kanai refers to here was originally titled Paul Cézanne im Gespräch mit Joachim Gasquet (released in 1989), has audio tracks in both French and German, was released under the title Cézanne and subtitled in Japanese. Coincidentally, Straub and Huillet released another film on Cézanne entitled Une Visite au Louvre (A Visit to the Louvre) in 2004, the year after Kanai published this essay.
} 
children of the neighborhood chasing each other and playing; sometimes they would play at jostling each other around him, raising their shrill voices, and he would half capture in photos how they played at attacking his space. Or else, in the midst of the wind that blew through the open space under a patched up tent, he would watch the foremost row of women, naughty boys, and childish Arabs go round to a flimsy tune on the small carousel; those two young girls from the hotel would cling to each other; their bodies stiff and a heavy look on their faces, whether they were riding on the pig, the goose, the swan, the horse, or the rusty bicycle; but when the roundabout began to slow and then stopped, their eyes, which were sparkling with delight, would stare entreatingly at him, upon which cue he would simply nod; but meanwhile an expression of ecstatic light would float upon his face and for all the world he would inevitably take his purse made from the same leather as those shoes out of his pocket: one more time, just one more time please. ..." .6 And, I should mention, I remember it because the bottom left hand side of a page in this book is folded into a scalene triangle so that it almost magically opens; and yet it is not anywhere here; it is almost like a film that isn't being projected onto the screen, even though a projector is turning; can it be that right now these photographs I cannot see are demanding that I watch the long, panoramic hand-held shot that Montès took, half playfully, of the hotel window and the village green?

In other words, Simon's photographs' visual charm resides in the fact that they are almost other-worldly. Similarly, the commemorative family photograph depicted in Ishii's $A$ Story of Youth (included, of course, in the original illustrated monochrome version) is simply a photograph of a post-Meiji era family, and its visual charm is surely that: unless we are one of the relatives of the people in the photo, it, too, is other-worldly. Standing behind the family were those heliographs; canna lilies with their large, uniquely-shaped leaves and red flowers that had overgrown like a thicket of trees, growing taller than the adults; which means that the bright summer sunshine must have poured onto them, and I suppose that

\footnotetext{
${ }^{6}$ In this paragraph, Kanai cites a lengthy passage from Hiraoka Tokuyoshi's translation of Claude Simon's novel Le Vent (1957). Simon's prose style can be distinguished by its use of free indirect speech and long sentences that often span many pages. By not indenting the citation, and moreover, by embedding it entirely within her own extremely long sentence, Kanai's essay re-enacts Simon's mode of writing. Simon's novel has been translated into English by Richard Howard as The Wind (1959), but here I have translated Hiraoka's Japanese version.
} 
the young Momoko found it difficult to keep still in the bright light. At any rate, the photograph's failure to capture Momoko's face in that light means that her presence there creates a strong impression on us, and it is precisely her blurred face's sense of presence which, I wish to contend, Simon's photographs all similarly hold. Thus, we calculate the distance between ourselves and the photograph through time, and yet, movement and time are two things that light cannot stop painting.

But there is a little thing I would like you to do for me. I want a photograph of you....

(Oscar Wilde, Lady Windermere's Fan, 1892)

When Mrs. Erlynne - who leaves without confessing that she is Lady Windermere's mother, having pocketed the fan (the article whose importance is indicated by its inclusion in the title and in its metonymic representation of Lady Windermere's "pride") - also then requests a portrait photograph of her daughter and her baby, this behavior might be seen, certainly in terms of its dramatic function in the play, as no more than a minor gesture, or footnote; nevertheless, it is arguable that portrait photographs, or the mug shot, are used as if they are proof of identity precisely because of the primitive desire, which could almost be described as a curse, to reproduce likeness, or which weekly magazines call "putting a face to the name."

While many clamor for a photograph of their beloved so that they may look at it and check that it is them, Gregory Peck, in contrast, robs potential viewers of a set of photographs that have been illicitly taken with Eddie Albert's mini-camera, of iconic moments showing Princess Ann having a day out in Rome; he instead hands them to Audrey Hepburn as "a memento." But what do these photographs mean? As a photographer for a media outfit, when Eddie points his camera at Audrey and closes its shutter, it is so that he can inform his audience through the repetitive candor of successive photographic frames; in the eyes of news media readers, who hanker to see them, the way these photographs are 
able to halt time through the medium of freeze-frame undoubtedly lends them an ability to impart the truth. ${ }^{7}$

This is again the case in Funny Face, when, for the second time in her career, Audrey is turned into a set of photographs that fulfill the function of imparting the truth within the frame of the moving picture (not counting the various bromide and still photographs and double page magazine splashes of her at home) and here too, all such photographs/snapshots of truth are freeze-frame.

With the exception of François Truffaut's The 400 Blows, films that do not provide a clear conclusion to the story, but which suddenly freeze the frame to display instead pseudo-photographic images, are as cheap and tacky as the sort of novels that wind up instructing you, the reader, "to write the rest of this unfinished story"; and, in my opinion, the way they seek to replicate the clicking of the camera's shutter is equally so.

So, when someone in a film snaps the camera's shutter, how should we be shown the photographs taken? There are numerous methods: in Jean-Luc Godard's Masculine Feminine, Jean-Pierre Leaud, who is holding a camera in order to take a photograph of his girlfriend on top of a roof, takes a step back in trying to find an angle he likes through the viewfinder, and falls off the roof backwards, still holding the camera; or, in relation to freeze-frame images, there is a scene in Every Man for Himself where a young woman is hit by a man and her hair creates a gently swirling blur, as if the film is being repeatedly interrupted. This puts me in mind of Tsutsui Takefumi, who writes in "Godard 1979, or On Godard's Classical Features": "Strictly speaking, this does not create a uniform slow-motion effect of drawing out time, as the frame is continually halted at an uneven rate. However, this jerky movement appears suddenly in the middle of a frame run at normal speed. It's like a photographic strip. The effect therefore, is not created through filming, but rather by reproducing the frame with an optical printer and cutting it in an editorial suite (this is easily done with a video recording, but takes time to achieve with film)." ${ }^{8}$ I also think of Alfred

\footnotetext{
${ }^{7}$ Kanai's essay here italicizes the term shashin (photograph) in pointing out that photographs are assumed by viewers to impart some kind of truth, and in so doing emphasises the double meaning of the term, whose kanji characters, 写真, literally means "to impart truth."

8 Here Kanai cites the pamphlet that accompanies the Japanese special edition DVD of Sauve qui peut/la vie (Every Man for Himself, 1980) by Jean-Luc Godard.
} 
Hitchcock's The Birds in which Tippi Hedren is similarly freeze-framed when witnessing the explosion of the gasoline stand from behind a window (although here it is rather that Hedren, for affect, performs freeze-frame herself); and Roberto Rossellini's The Machine to Kill Bad People, which retells the fable of the Devil's murderous camera in which the moment that the shutter of the camera closes, the subject of that photograph is called to their death.

The box-shaped camera that a fishing village camera shop receives from the Devil has the power to kill the subjects of the exposures by the time they are printed as photographs; and as death is thus brought on by the simple mechanical act of taking a photo, here freeze-frame provides an easy means to produce photographs, or stills, within the film that are completely unrelated to it. (At the time of its production, people talked about how the unrelatedness, or rather, the indirect nature, of pressing a button was metaphorical for nuclear-button warfare.)

Might stills and blurs therefore be understood as a kind of perversion of, or marriage between, movement and stasis; as effects created by reproducing the frame with an optical printer and cutting it in an editorial suite: that "light," which both cinematograph and photograph have in common; which blurred Momoko's face with its brightness; which refused Simon's photographs a focus; and about which the director of Passion repeatedly grumbled ("the light is no good"); "light" was the reason Straub and Huillet made a film about Cézanne; and, it goes without saying, that because (is it because?) the perverted light of movement and stasis filters into the creation of films, it also enables the formation of novels through words. 